\title{
Potential of Gibberellic Acid (GA3) and Uniconazole for Enhancing the Cd Absorption Efficiency of Maize (Zea mays L.)
}

\author{
Kaining Sun ${ }^{\#}$, Yaoquan Yue ${ }^{2 \#}$, Haoran Zhang², Ning Yang', Dan Wen', Xuhua Li³, \\ Ning Chen², Yanjie Yang ${ }^{2}$, Kean Wang ${ }^{1 *}$ \\ ${ }^{1}$ Institute of Vegetables and Flowers, Shandong Academy of Agricultural Sciences, Shandong Branch of National \\ Improvement Center for Vegetables, Huang-Huai-Hai Region Scientific Observation and Experimental Station \\ of Vegetables, Ministry of Agriculture and Rural Affairs, Shandong Key Laboratory of Greenhouse Vegetable Biology, \\ Jinan, Shandong, 250100, People's Republic of China \\ ${ }^{2}$ College of Horticulture, Qingdao Agricultural University, Qingdao, Shandong, 266109, People's Republic of China \\ ${ }^{3}$ National Engineering Laboratory for Efficient Utilization of Soil and Fertilizer Resources, College of Resources and \\ Environment, Shandong Agricultural University, Tai' an, Shandong, 271018, People's Republic of China
}

Received: 27 March 2020

Accepted: 12 June 2020

\begin{abstract}
In this study, gibberellic acid 3 (GA3) and uniconazole were applied as the means of improving of cadmium $(\mathrm{Cd})$ polluted site phytoremediation using maize (Zea mays L.). The results showed that GA3 $(40 \mathrm{mg} / \mathrm{L})$, and uniconazole $(800 \mathrm{mg} / \mathrm{L})$ could increase the biomass, plant height, stem diameter, leaf area, and root parameters of maize plants under Cd stress $(0.4 \mathrm{mg} / \mathrm{L})$ by foliar spraying. GA3 $(40 \mathrm{mg} / \mathrm{L})$ could increase the SPAD value of maize leaves by $23.45 \%$ and the net photosynthetic rate by $645.93 \%$. Both plant regulators could alleviate the oxidative damage of maize and increase the activity of SOD and POD up to $11.44 \sim 58.41 \%$ and $35.00 \sim 99.55 \%$, respectively. The content of MDA and $\mathrm{H}_{2} \mathrm{O}_{2}$ could be reduced by GA3 to $31.91 \%$ and $24.77 \%$, respectively. GA3 at $40 \mathrm{mg} / \mathrm{L}$ could significantly increase the accumulation of $\mathrm{Cd}$ ions in the shoots, roots and whole plants of maize by $222.01 \%, 603.13 \%$ and $341.70 \%$, respectively, showing the best effect among tested treatments. It was found that the application of plant growth regulators (PGRs) could increase the biomass and Cd concentration in maize organs, ultimately achieving the purpose of improving the remediation efficiency of $\mathrm{Cd}$ by increasing the absolute content of $\mathrm{Cd}$ in maize biomass.
\end{abstract}

Keywords: facility soil, cadmium, phytoremediation, gibberellin, uniconazole 


\section{Introduction}

Cadmium (Cd) is a widely recognized toxic heavy metal that seriously harms soil environment and human health. It can enter agricultural soil through many ways, such as atmospheric settlement, mining, industrial waste, sewage irrigation and excessive application of fertilizers $[1,2]$. Cd gradually accumulates in the soil but cannot be degraded by biological processes. Over time, this process negatively impacts soil biodiversity and microbial activity and reduces soil fertility [3]. Cd has certain biological availability in soil, and is easily absorbed and accumulated by different parts of plants (such as roots, stems, leaves, fruits, etc.), thus adversely affecting animal and human health through the food chain [4].

In recent years, facility agriculture has gradually become one of the main modes of vegetable production in China [5]. According to China's official bulletin, the total amount of heavy metal pollution in soil exceeds $16.1 \%$, and soil $\mathrm{Cd}$ pollution ranks first, with a pollution percentage of $7.0 \%$ [6]. In 2016, Shandong province accounted for a quarter of China's total output of facility vegetables and was the main producing area of facility vegetables [7]. According to the latest research in 2019, through the statistical analysis of the heavy metal content in the soil of representative vegetable production areas in Shandong province, the geological accumulation index of $\mathrm{Cd}$ is between no pollution and moderate pollution, and up to $13.1 \%$ of the samples exceed the Cd limit value of $0.3 \mathrm{mg} \mathrm{kg}{ }^{-1}$ stipulated in the agricultural industry standard (NY 5294-2004) [8]. Therefore, in order to ensure the production of vegetables of high quality, heavy metals must be removed from contaminated soil to prevent $\mathrm{Cd}$ from entering the human food supply.

Conventional methods, including physical and chemical methods, have been used for the recovery of heavy metal contaminated soils [9]. However, these methods are costly and labor-intensive, often damage the soil environment and lead to irreversible changes in soil properties. Compared with the physical and chemical methods, phytoremediation is a cost-effective and environmentally friendly method [10]. It has been used to purify various pollutants, including metals, nonmetals, petroleum and other organic pollutants [11]. However, plants under heavy metal polluted soil conditions are usually characterized by low biomass, slow growth and low heavy metal enrichment [12].

In order to achieve efficient heavy metal phytoremediation, plant biomass should be increased, and the ability to tolerate and accumulate higher concentrations of heavy metals should be improved. Plants with high heavy metal tolerance usually have low biomass, and many plants with high biomass cannot tolerate high concentrations of heavy metals. In order to realize the potential of increasing plant biomass and plant tolerance to heavy metals, several attempts have been made (applied to plants or added to soil/water), including agricultural strategies and chemical agents (such as plant growth regulators) to improve the efficiency of phytoremediation [13]. Gibberellins (GAs) are diterpenoid and phytohormone that has been widely used in agricultural production, which is capable of activating cell division and cell proliferation processes $[14,15]$. Because GA can overcome apical dominance, it is easy to visually observe that it promotes stem growth [16]. Uniconazole is a potential plant growth regulator that can protect plants against high temperature stress, salinity stress, drought stress and water stress [17-20]. Studies have shown that the application of uniconazole can increase the activity of antioxidant enzymes and reduce the accumulation of malondialdehyde (MDA) in maize [21]. The application of uniconazole can improve photosynthetic efficiency, chlorophyll content and antioxidant enzyme activity of soybean, thus improving the yield [22].

Facility vegetables usually have a long planting time during the summer leisure season (from June to August). Therefore, it is necessary to select $\mathrm{Cd}$ restoration plants with a fast growth rate and high biomass, which are suitable for growing during this period. Maize belongs to thermophilic crops with a short growth cycle and much higher biomass than the general heavy metal enrichment plants. Based on the above analysis, this paper studied the effects of two PGRs (GA3 and uniconazole) on the growth status, tolerance and absorption efficiency of phytoremediation crops (maize) under $\mathrm{Cd}$ stress. It provides preliminary support for the next stage of phytoremediation of vegetable fields contaminated by $\mathrm{Cd}$, and provides a feasible reference for the heavy metal phytoremediation scheme.

\section{Materials and Methods}

\section{Plant Materials and Planting Methods}

The tested maize variety was Haowei 556 (Gansu wuwei haowei garden planting co., LTD.). Selected seeds should be full and uniform in size. The method of planting in the plugs was adopted. The plugs (Taizhou Longji Plastic Industry Co., Ltd.) had a specification of $540 \times 280 \times 110 \mathrm{~mm}(\mathrm{~L} \times \mathrm{W} \times \mathrm{H})$, and the volume was $190 \mathrm{~cm}^{3}$ per hole. The number of holes was 32 . The substrate was purchased from Jinan Yubeng Biotechnology Co., Ltd. Hoagland nutrient solution was prepared and $\mathrm{CdCl}_{2}$ was added to reach a concentration of $0.4 \mathrm{mg} / \mathrm{L}$. The nutrient solution was then applied to the substrate.

\section{Test Arrangement}

The experiment was conducted in the solar greenhouse of Shandong Academy of Agricultural Sciences from January to February 2019. The experimental treatments are shown in Table 1. The 
Table 1. The types and concentrations of exogenous PGRs sprayed in each treatment.

\begin{tabular}{|c|c|c|}
\hline Treatments & $\begin{array}{c}\text { Exogenous plant growth } \\
\text { regulator }\end{array}$ & Concentration \\
\hline CK & Distilled water & - \\
\hline A1 & Uniconazole & $200 \mathrm{mg} / \mathrm{L}$ \\
\hline A2 & Uniconazole & $800 \mathrm{mg} / \mathrm{L}$ \\
\hline A3 & GA3 & $10 \mathrm{mg} / \mathrm{L}$ \\
\hline A4 & GA3 & $40 \mathrm{mg} / \mathrm{L}$ \\
\hline
\end{tabular}

In the table, different letters indicate a significant $(p<0.05)$ difference between treatments in the same experiment.

treatments were arranged randomly with three replicates. During the experiment, PGRs (Uniconazole: $200 \mathrm{mg} / \mathrm{L}$ and $800 \mathrm{mg} / \mathrm{L}$. GA3: $10 \mathrm{mg} / \mathrm{L}$ and $40 \mathrm{mg} / \mathrm{L}$ ), purchased from Beijing Solarbio Technology Co., LTD, were prepared with distilled water and sprayed every 10 days and CK was distilled water. The net photosynthetic rate of maize was measured on the $20^{\text {th }}$ day of maize growth. At the $30^{\text {th }}$ day, the shoots and roots of maize were harvested separately and washed with distilled water. A portion of the samples was dried, crushed and stored in sealed bags for preservation. The other fresh samples were used for enzyme detection and stored at $-80^{\circ} \mathrm{C}$ after treatment with liquid nitrogen.

\section{Plant Growth Parameters}

Plant height was measured with a centimeter ruler at harvest. The plants were collected separately according to shoots and roots, and the fresh weight was measured. The dry weight was measured by drying at $105^{\circ} \mathrm{C}$ for $30 \mathrm{~min}$ and then at $70^{\circ} \mathrm{C}$ until the weight became constant. The stem diameter was measured by an electronic caliper to determine the narrow width of the midpoint between the first nodes above the aerial root. To measure leaves area, root tips, root volume and total root length, the leaves or roots were arranged and floated on shallow water in a glass tray $(30 \mathrm{~cm} \times 30 \mathrm{~cm})$, scanned using a scanner (Epson Expression 1680 Scanner, Seiko Epson Corp., Tokyo, Japan), and then analyzed using WinRHIZO Analyzer System (Regent Instruments Inc., Quebec, Canada).

\section{Relative Chlorophyll Content (SPAD) and Net Photosynthetic Rate}

Leaves from the same parts of maize were selected and SPAD value was measured by a chlorophyll meter (SPAD-502 plus, China). The net photosynthetic rate was measured with a photosynthetic apparatus (Li-6400xt, USA).

\section{Malondialdehyde (MDA) Content}

The MDA content was measured with reference to Chaoui et al. [23]. A total of $0.2 \mathrm{~g}$ fresh maize leaves were mixed with $10 \%(\mathrm{w} / \mathrm{v})$ TCA $(10 \mathrm{~mL})$ and centrifuged at $3000 \mathrm{rpm}$ for $10 \mathrm{~min}$. The supernatant (2 mL) was thoroughly mixed with $10 \%$ TCA $(2 \mathrm{~mL})$ containing $0.5 \% \mathrm{TBA}$ and heated at $95^{\circ} \mathrm{C}$ for $30 \mathrm{~min}$, followed by rapid cooling in an ice bath. The content of MDA was determined at wavelengths of 532, 600 and $450 \mathrm{~nm}$.

$$
\mathrm{H}_{2} \mathrm{O}_{2} \text { Content }
$$

The $\mathrm{H}_{2} \mathrm{O}_{2}$ content was determined by the method of Velikova et al. [24]. Leaf tissue $(0.2 \mathrm{~g})$ was thoroughly ground and mixed with $3 \mathrm{~mL}$ of $0.1 \%(\mathrm{w} / \mathrm{v})$ trichloroacetic acid (TCA) in an ice bath, followed by centrifugation at $12,000 \mathrm{rpm}$ for $15 \mathrm{~min}$. Phosphate buffer $(0.5 \mathrm{ml}, \mathrm{pH} 7.0)$ and $1 \mathrm{~mL} \mathrm{KI}(1 \mathrm{M})$ were added to the supernatant. The absorbance was read at $390 \mathrm{~nm}$.

\section{Antioxidant Enzyme Activity}

The leaves were cut and placed in a bowl, which were homogenated in $50 \mathrm{~mm} \mathrm{Na} \mathrm{HPO}_{4}-\mathrm{NaH}_{2} \mathrm{PO}_{4}$ buffer ( $\mathrm{pH}$ 7.8) containing $0.2 \mathrm{~mm}$ EDTA and $2 \%$ insoluble polyvinylpyrrolidone. The homogenate was centrifuged at $3500 \mathrm{rpm}$ for $20 \mathrm{~min}$ at $4^{\circ} \mathrm{C}$. The supernatant was used to determine the enzyme activity using a spectrophotometer (Unico UV2100, USA). The SOD activity was measured by measuring the inhibitory effect of SOD on photochemical reduction of nitroblue tetrazolium [25]. The CAT activity was determined by measuring the absorbance at $240 \mathrm{~nm}$ [26]. The POD activity was determined by measuring the absorbance of guaiacol at $470 \mathrm{~nm}$ [27].

\section{Proline Content}

The determination of proline was performed using the method of Bates [28]. Fresh maize leaves $(500 \mathrm{mg})$ were extracted with 3\% 5-thiosalicylic acid solution and centrifuged at $5000 \mathrm{rpm}$. The absorbance of the supernatant was determined at $520 \mathrm{~nm}$.

\section{Vitamin E Content}

The vitamin E content was determined using a commercial kit purchased from Nanjing Jiancheng Bioengineering Institute, China [29]. Accurately weigh the samples, added the extraction solution in the kit according to the weight $(\mathrm{g})$ : volume $(\mathrm{mL})=1$ : 9 ratio, fully homogenized, and centrifuged at $25^{\circ} \mathrm{C}$ with a centrifuge $(2500 \mathrm{rpm})$ for 10 Minutes, then taking the supernatant for testing. Added the reaction solution in the kit to the test solution, mixed thoroughly, and let stand for $2 \mathrm{~min}$, adjusted to zero with absolute ethanol, and measured the absorbance at $533 \mathrm{~nm}$. 
Table 2. Effects of uniconazole and GA3 on maize biomass under Cd stress.

\begin{tabular}{|c|c|c|c|c|c|c|}
\hline \multirow{2}{*}{ Treatments } & \multicolumn{2}{|c|}{ Roots } & \multicolumn{2}{c|}{ Shoots } & \multicolumn{2}{c|}{ Entire plant } \\
\cline { 2 - 7 } & $\begin{array}{c}\text { Fresh biomass } \\
(\mathrm{g}) \pm \mathrm{SD}\end{array}$ & $\begin{array}{c}\text { Dry biomass }(\mathrm{g}) \\
\pm \mathrm{SD}\end{array}$ & $\begin{array}{c}\text { Fresh biomass } \\
(\mathrm{g}) \pm \mathrm{SD}\end{array}$ & $\begin{array}{c}\text { Dry biomass }(\mathrm{g}) \\
\pm \mathrm{SD}\end{array}$ & $\begin{array}{c}\text { Fresh biomass } \\
(\mathrm{g}) \pm \mathrm{SD}\end{array}$ & $\begin{array}{c}\text { Dry biomass }(\mathrm{g}) \\
\pm S D\end{array}$ \\
\hline $\mathrm{CK}$ & $2.27 \pm 0.53 \mathrm{c}$ & $0.22 \pm 0.06 \mathrm{c}$ & $7.35 \pm 1.33 \mathrm{c}$ & $0.66 \pm 0.20 \mathrm{~b}$ & $9.62 \pm 1.55 \mathrm{c}$ & $0.87 \pm 0.25 \mathrm{~b}$ \\
\hline $\mathrm{A} 1$ & $2.81 \pm 0.11 \mathrm{c}$ & $0.24 \pm 0.02 \mathrm{c}$ & $10.15 \pm 0.44 \mathrm{bc}$ & $0.88 \pm 0.19 \mathrm{~b}$ & $12.96 \pm 0.54 \mathrm{~b}$ & $1.13 \pm 0.20 \mathrm{~b}$ \\
\hline $\mathrm{A} 2$ & $3.85 \pm 0.48 \mathrm{~b}$ & $0.37 \pm 0.04 \mathrm{~b}$ & $12.44 \pm 2.62 \mathrm{~b}$ & $1.37 \pm 0.26 \mathrm{a}$ & $16.29 \pm 3.09 \mathrm{~b}$ & $1.74 \pm 0.26 \mathrm{a}$ \\
\hline $\mathrm{A} 3$ & $2.26 \pm 0.17 \mathrm{c}$ & $0.21 \pm 0.02 \mathrm{c}$ & $11.10 \pm 0.77 \mathrm{~b}$ & $0.95 \pm 0.16 \mathrm{~b}$ & $13.37 \pm 0.61 \mathrm{~b}$ & $1.16 \pm 0.14 \mathrm{~b}$ \\
\hline A4 & $5.07 \pm 0.38 \mathrm{a}$ & $0.49 \pm 0.06 \mathrm{a}$ & $18.53 \pm 1.73 \mathrm{a}$ & $1.49 \pm 0.12 \mathrm{a}$ & $23.60 \pm 2.01 \mathrm{a}$ & $1.99 \pm 0.15 \mathrm{a}$ \\
\hline $\begin{array}{c}\text { F value at } \\
p<0.05\end{array}$ & 31.28 & 21.05 & 20.68 & 10.30 & 25.00 & 15.04 \\
\hline
\end{tabular}

In the table, different letters indicate a significant $(p<0.05)$ difference between treatments in the same experiment.

\section{Cd content in Plants}

For $\mathrm{Cd}$ analysis, the dried maize samples were digested in a mixture of $\mathrm{HNO}_{3} / \mathrm{HClO}_{4}(3 / 1, \mathrm{v} / \mathrm{v})$, at $150^{\circ} \mathrm{C}$ for $2 \mathrm{~h}$ and $210^{\circ} \mathrm{C}$ for $1 \mathrm{~h}$, and then dissolved in $\mathrm{HCl}(0.5 \mathrm{~N})$. The concentration of $\mathrm{Cd}$ was determined by an atomic absorption spectrometer (Persee tas-986, China). Per plant (by roots and shoots) Cd accumulation was calculated as follows [30].

Total Cd accumulation by roots/shoots ( $\mu \mathrm{g} /$ plant)

$=$ Dry biomass of roots/shoots $(\mathrm{g}) \times \mathrm{Cd}$ concentration $(\mu \mathrm{g} / \mathrm{g}$ dry $\mathrm{wt})$ by roots/shoots

\section{Calculation of Translocation Factor (TF) and Concentration Index (CI) of $\mathrm{Cd}$}

The translocation factor was calculated according to the following equation:

$$
\text { Translocation factor }(\mathrm{TF})=\frac{C \text { aerial }}{C \text { root }}
$$

...where, $C$ represents the concentration of metal in aerial or root $(\mu \mathrm{g} / \mathrm{g})$.

The concentration index (CI) was calculated by dividing the $\mathrm{Cd}$ concentration of the treated plants by the $\mathrm{Cd}$ concentration of the control plants as shown in the following equation [31]:

$$
\text { Concentration index }(\mathrm{CI})=
$$

Concentration of metal in treated plant Concentration of metal in control plant

\section{Data Analysis}

SPSS 21 software was used for one-way analysis of variance (ANOVA). The data were expressed as mean \pm standard error (SE) of three replicates. Duncan test was used to determine statistical significance when the probability level was $P<0.05$. Plotting was done by SigmaPlot 12.5.

\section{Results}

Effects of PGRs (Uniconazole and GA3) on the Growth of Maize under Cd Stress

These two PGRs (GA3 and uniconazole) at different concentrations could significantly affect the biomass of roots, shoots and the entire plant (Table 2). In the roots section, the fresh and dry weight of uniconazole $(800 \mathrm{mg} / \mathrm{L})$ increased by $69.60 \%$ and $68.18 \%$, respectively. Meanwhile, GA3 (40 mg/L) increased by $123.3 \%$ and $122.7 \%$, respectively. Compared with $\mathrm{CK}$, the changes above were significantly different $(p<0.05)$. In the shoots section, GA3 $(40 \mathrm{mg} / \mathrm{L})$ increased the fresh and dry weight of by $152.11 \%$ and $125.76 \%$, and uniconazole $(800 \mathrm{mg} / \mathrm{L})$ increased by
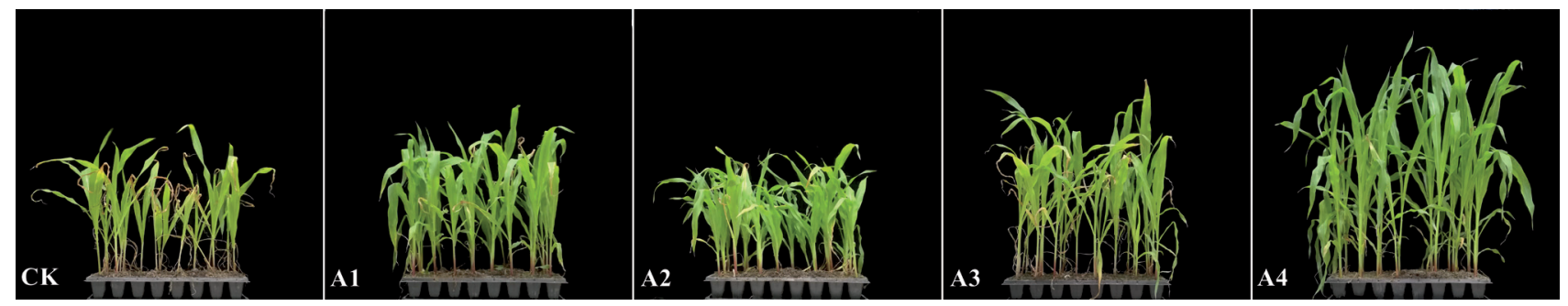

Fig. 1. Maize treated with GA3 and uniconazole under Cd stress. 
Table 3. Effects of uniconazole and GA3 on main growth parameters (plant height, stem diameter, leaves area, root volume, root tips and total root length) of maize under Cd stress.

\begin{tabular}{|c|c|c|c|c|c|c|}
\hline Treatments & $\begin{array}{c}\text { Plant height } \\
(\mathrm{cm})\end{array}$ & $\begin{array}{c}\text { Stems diameter } \\
(\mathrm{cm})\end{array}$ & $\begin{array}{c}\text { Leaves area } \\
\left(\mathrm{cm}^{2}\right)\end{array}$ & $\begin{array}{c}\text { Root Volume } \\
\left(\mathrm{cm}^{3}\right)\end{array}$ & Root tips & $\begin{array}{c}\text { Total root length } \\
(\mathrm{cm})\end{array}$ \\
\hline CK & $50.11 \pm 4.17 \mathrm{~b}$ & $0.81 \pm 1.61 \mathrm{~b}$ & $217.83 \pm 60.51 \mathrm{bc}$ & $1.704 \pm 0.35 \mathrm{~b}$ & $5577.40 \pm 1730.57 \mathrm{bc}$ & $618.35 \pm 244.71 \mathrm{~b}$ \\
\hline A1 & $41.56 \pm 2.60 \mathrm{c}$ & $0.83 \pm 1.16 \mathrm{~b}$ & $286.82 \pm 58.99 \mathrm{~b}$ & $1.45 \pm 0.43 \mathrm{bc}$ & $4187.00 \pm 1912.00 \mathrm{~cd}$ & $452.96 \pm 207.62 \mathrm{bc}$ \\
\hline A2 & $42.11 \pm 3.30 \mathrm{c}$ & $0.99 \pm 2.67 \mathrm{a}$ & $252.09 \pm 40.14 \mathrm{~b}$ & $2.445 \pm 0.70 \mathrm{a}$ & $6928.80 \pm 1511.95 \mathrm{~b}$ & $655.25 \pm 126.71 \mathrm{~b}$ \\
\hline A3 & $51.22 \pm 4.09 \mathrm{~b}$ & $0.77 \pm 1.01 \mathrm{~b}$ & $158.20 \pm 62.50 \mathrm{c}$ & $0.949 \pm 0.13 \mathrm{c}$ & $2644.40 \pm 981.69 \mathrm{~d}$ & $252.15 \pm 80.73 \mathrm{c}$ \\
\hline A4 & $77.00 \pm 3.57 \mathrm{a}$ & $1.00 \pm 0.94 \mathrm{a}$ & $358.05 \pm 56.08 \mathrm{a}$ & $2.433 \pm 0.36 \mathrm{a}$ & $11422.40 \pm 1599.38 \mathrm{a}$ & $1283.20 \pm 163.94 \mathrm{a}$ \\
\hline $\begin{array}{c}\text { F value at } \\
p<0.05\end{array}$ & 145.81 & 4.56 & 10.63 & 8.91 & 22.51 & 24.56 \\
\hline
\end{tabular}

In the table, different letters indicate a significant $(p<0.05)$ difference between treatments in the same experiment.

$69.25 \%$ and $107.58 \%$, all of which reached a significant level $(p<0.05)$. The results showed that uniconazole $(800 \mathrm{mg} / \mathrm{L})$ and GA3 (40 $\mathrm{mg} / \mathrm{L})$ could significantly increase the maize plant biomass (shoots, roots system) under Cd stress.
Compared with CK (Fig. 1; Table 3), the plant height of the maize treated with GA3 $(40 \mathrm{mg} / \mathrm{L})$ increased by $53.66 \%$, while uniconazole $(200 \mathrm{mg} / \mathrm{L}$ and $800 \mathrm{mg} / \mathrm{L})$ decreased by $17.06 \%$ and $15.96 \%$, respectively. GA3 $(40 \mathrm{mg} / \mathrm{L})$ and uniconazole $(800 \mathrm{mg} / \mathrm{L})$ significantly
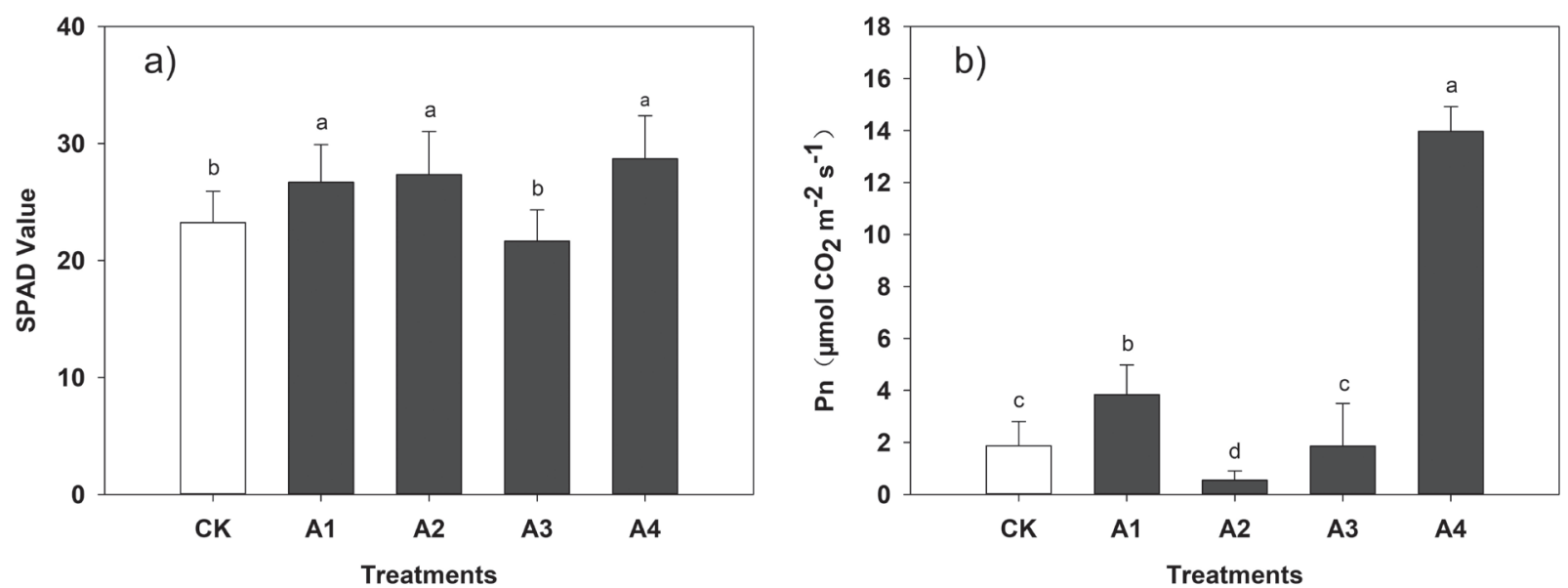

Fig. 2. Effects of uniconazole and GA3 on SPAD value a) and net photosynthetic rate b) of maize leaves under Cd stress.
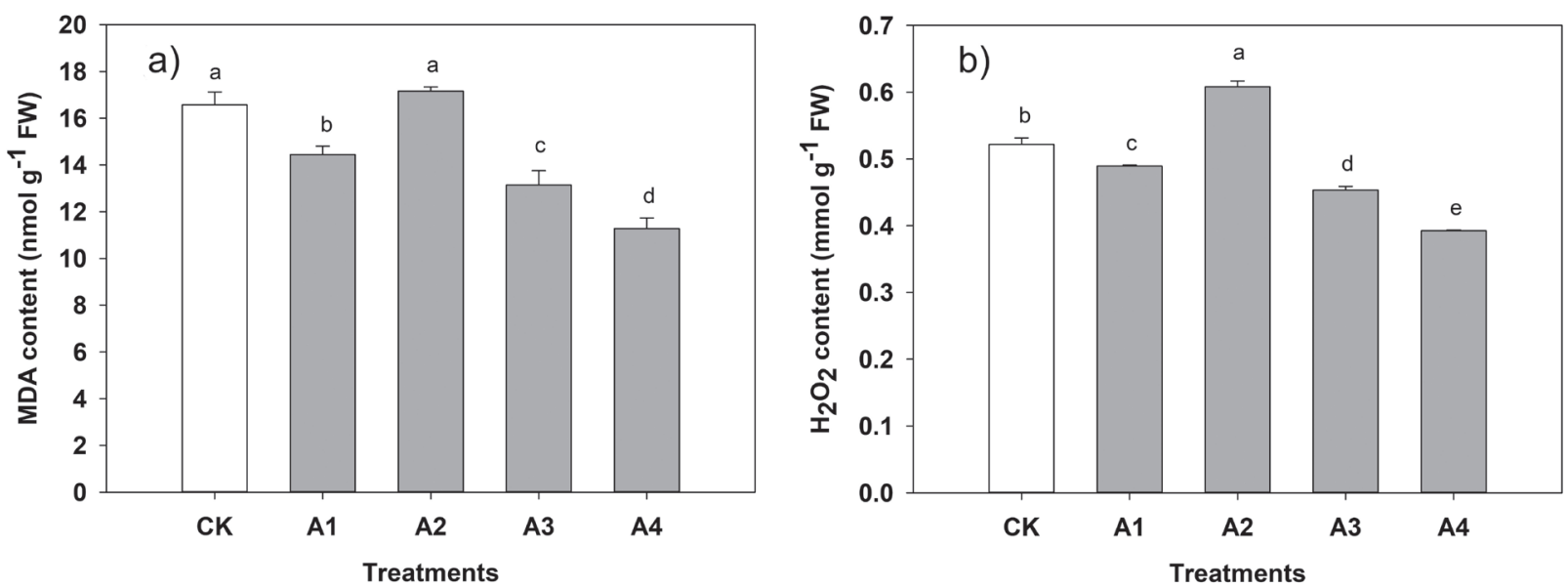

Fig. 3. Effects of uniconazole and $\mathrm{GA} 3$ on MDA a) and $\mathrm{H}_{2} \mathrm{O}_{2}$ b) of maize leaves under $\mathrm{Cd}$ stress. 

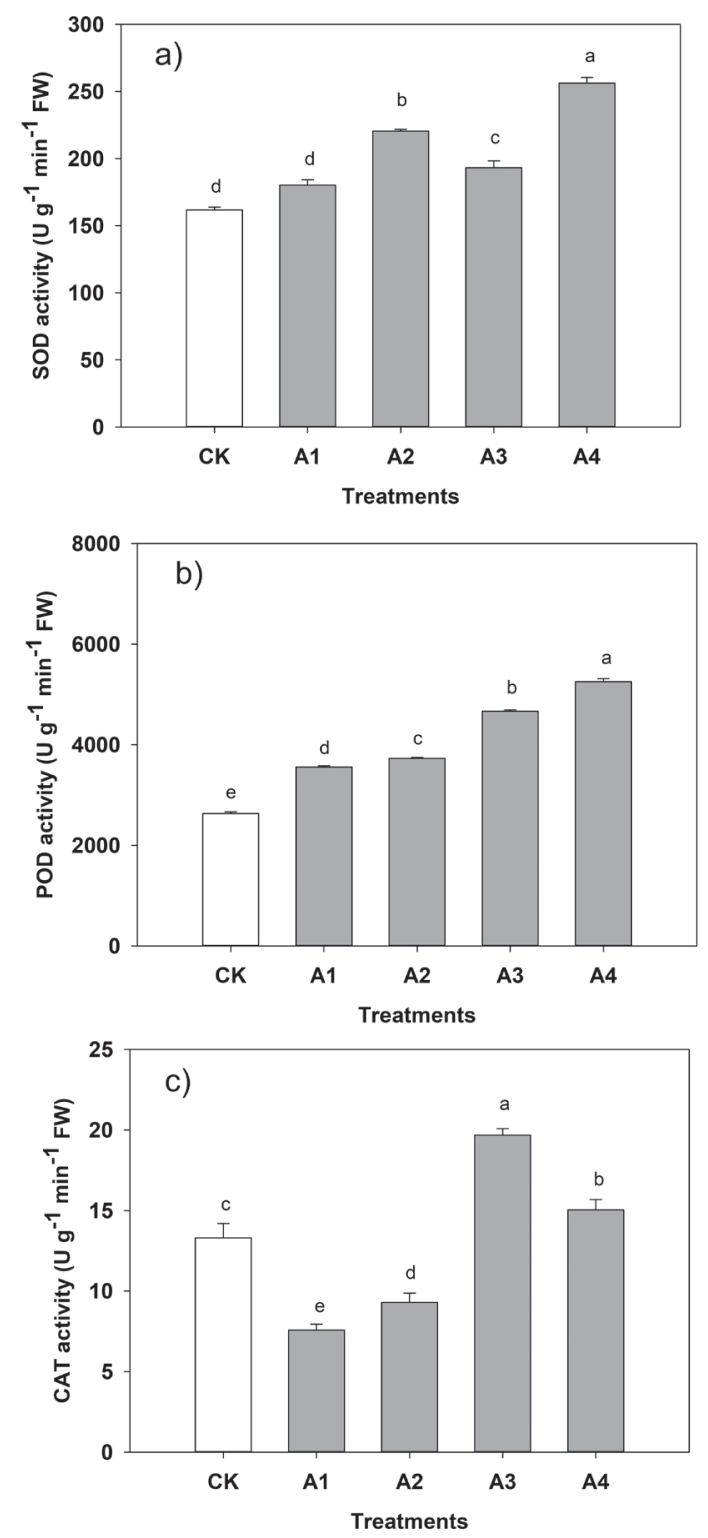

Fig. 4. Effects of uniconazole and GA3 on SOD a), POD b) and CAT c) in maize leaves. increased the stem diameter by $23.46 \%$ and $22.22 \%$ $(p<0.05)$, respectively. GA3 $(40 \mathrm{mg} / \mathrm{L})$ increased the leaf area significantly by $64.37 \% \quad(p<0.05)$. In terms of roots, uniconazole $(800 \mathrm{mg} / \mathrm{L})$ significantly increased the root volume of the maize to $43.49 \%$ $(p<0.05)$. GA3 $(40 \mathrm{mg} / \mathrm{L}) \quad$ significantly $\quad(p<0.05)$ increased the root volume, root tip number and total root length of maize by $42.78 \%, 104.80 \%$ and $107.52 \%$, respectively.

\section{Effects of PGRs (Uniconazole and GA3) on SPAD Value and Photosynthesis of Maize Leaves under Cd Stress}

Compared with CK (Fig. 2a), the SPAD value of maize leaves under uniconazole (200 $\mathrm{mg} / \mathrm{L})$, uniconazole (800 $\mathrm{mg} / \mathrm{L})$ and GA3 (40 mg/L) was significantly increased $(p<0.05)$ by $14.82 \%, 17.639 \%$ and $23.45 \%$, respectively. However, the difference between uniconazole $(800 \mathrm{mg} / \mathrm{L})$ and CK did not reach a significant level $(p>0.05)$. Compared with CK (Fig. 2b), the net photosynthetic rate of plants under uniconazole $(200 \mathrm{mg} / \mathrm{L})$ and GA3 (40 mg/L) increased by $104.99 \%$ and $645.93 \%(p<0.05)$, respectively. There was no significant difference between GA3 (10 mg/L) and $\mathrm{CK}(p>0.05)$, and uniconazole $(800 \mathrm{mg} / \mathrm{L})$ was significantly lower than CK $(p<0.05)$.

Effects of PGRs (Uniconazole and GA3) on Oxidative Damages and Antioxidant Activities of Maize under Cd Stress

Compared with CK (Fig. 3a), MDA of uniconazole (200 mg/L), GA3 (10 mg/L) and GA3 (40 mg/L) decreased by $12.81 \%, 20.69 \%$ and $31.91 \%(p<0.05)$, respectively, while uniconazole $(800 \mathrm{mg} / \mathrm{L})$ and $\mathrm{CK}$ showed no significant differences $(p>0.05)$. The changing trend of the $\mathrm{H}_{2} \mathrm{O}_{2}$ content in maize leaves of each treatment was similar to that of MDA (Fig. 3b). Uniconazole $(800 \mathrm{mg} / \mathrm{L})$ increased the $\mathrm{H}_{2} \mathrm{O}_{2}$ content,
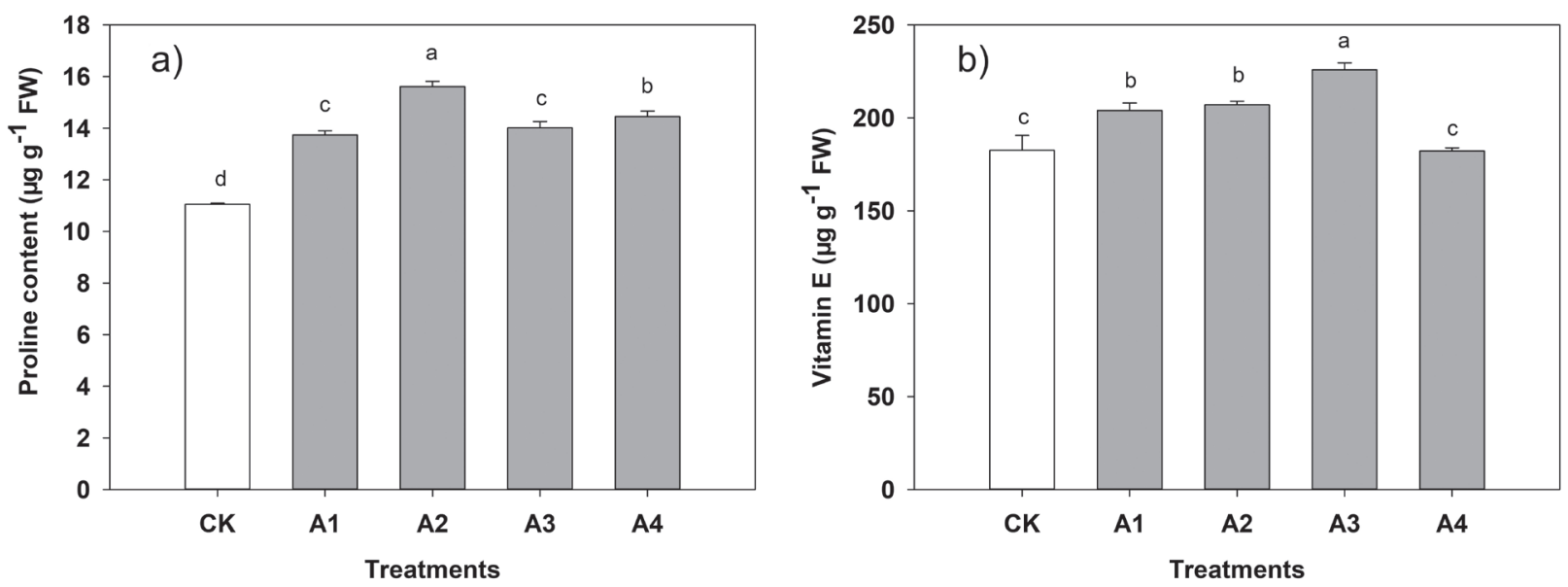

Fig. 5. Effects of uniconazole and GA3 on proline a) and vitamin E b) in maize leaves. 

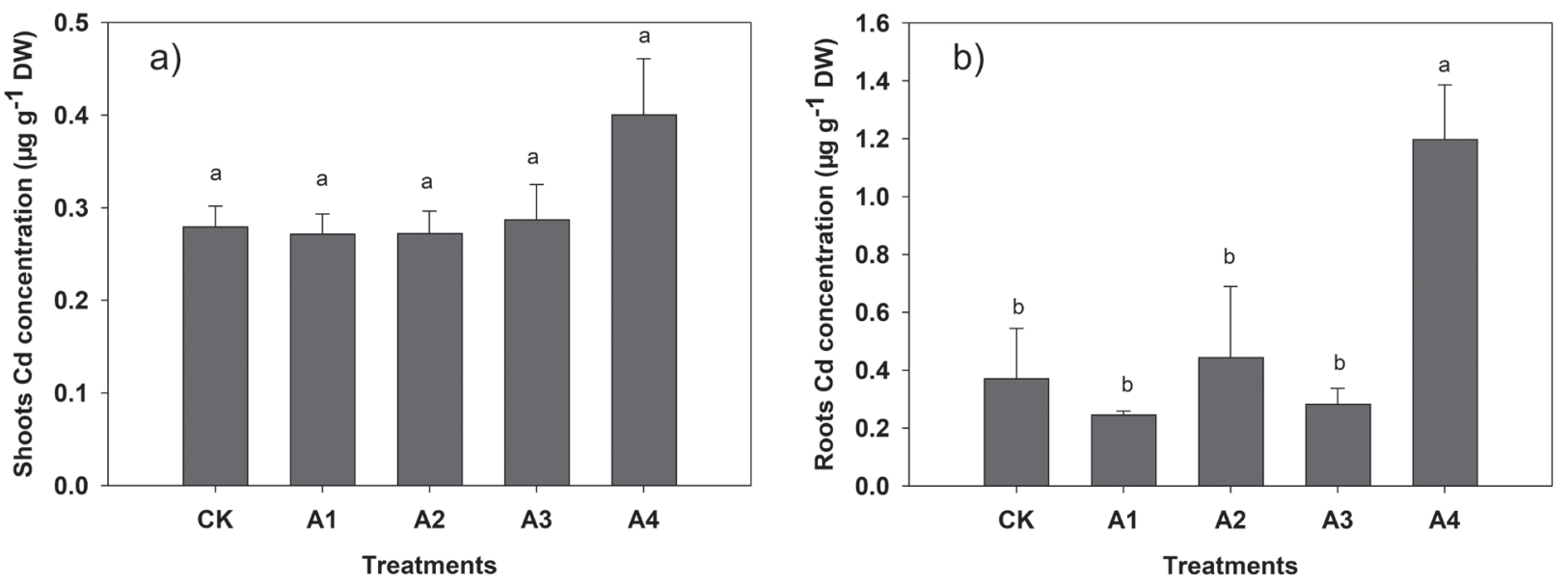

Fig. 6. Effects of uniconazole and GA3 on Cd concentrations in the upper a) and subterranean b) parts of maize.

while A4 showed the largest decrease among all treatments, reaching $24.77 \%$.

Compared with CK (Fig. 4a), SOD of each treatment increased to $11.44 \sim 58.41 \%$, and the difference between uniconazole $(800 \mathrm{mg} / \mathrm{L})$, GA3 $(10 \mathrm{mg} / \mathrm{L})$ and GA3 $(40 \mathrm{mg} / \mathrm{L})$ and $\mathrm{CK}$ was significant $(p<0.05)$ with GA3 $(40 \mathrm{mg} / \mathrm{L})$ being the highest. The order of the POD activity in each treatment was GA3 (40 mg/L)>GA3 $(10 \mathrm{mg} / \mathrm{L})>$ uniconazole $(800 \mathrm{mg} / \mathrm{L})>$ uniconazole $(200 \mathrm{mg} / \mathrm{L})>\mathrm{CK}$ with an increase of $35.00 \sim 99.55 \%$, and the difference was significant $(p<0.05)$ (Fig. 4b). In terms of the CAT activity (Fig. 4c), the difference between GA3 (10 mg/L), GA3 (40 mg/L) and CK was significant $(p<0.05)$, which was $47.95 \%$ and $13.03 \%$ higher than $\mathrm{CK}$, respectively, while uniconazole $(200 \mathrm{mg} / \mathrm{L})$ and uniconazole $(800 \mathrm{mg} / \mathrm{L})$ were smaller than $\mathrm{CK}$.

Both of uniconazole and GA3 could significantly increase the proline content in maize leaves (Fig. 5a). Compared with CK, uniconazole (200 mg/L), uniconazole $(800 \mathrm{mg} / \mathrm{L})$, GA3 $(10 \mathrm{mg} / \mathrm{L})$ and GA3 $(40 \mathrm{mg} / \mathrm{L})$ increased the proline content by $24.38 \%$, $41.35 \%, 26.89 \%$ and $30.78 \%$, respectively, and the difference reached a significant level $(p<0.05)$. Compared with $\mathrm{CK}$, the vitamin E content in leaves of uniconazole $(200 \mathrm{mg} / \mathrm{L})$, uniconazole $(800 \mathrm{mg} / \mathrm{L})$ and GA3 (10 mg/L) maize increased by $11.80 \%, 13.43 \%$ and $23.80 \%$ respectively (Fig. $5 \mathrm{~b}$ ), all of which were significantly different from CK $(p<0.05)$. , The proline content under GA3 (40 mg/L) decreased slightly with no significant difference from $\mathrm{CK}(p>0.05)$.

\section{Effects of PGRs (Uniconazole and GA3) on Cd Enrichment in Maize under Cd Stress}

As shown in Fig. 6, the $\mathrm{Cd}$ concentration in the shoots of the maize field treated with GA3 $(10 \mathrm{mg} / \mathrm{L})$ and GA3 (40 mg/L) increased by $2.83 \%$ and $43.31 \%$, respectively (Fig. 6a). However, the difference did not reach a significant level $(p>0.05)$. Compared with CK, uniconazole $(800 \mathrm{mg} / \mathrm{L})$ and GA3 (40 mg/L) could increase the concentration of maize roots $\mathrm{Cd}$ to $19.77 \%$ and $222.49 \%$ respectively (Fig. $6 \mathrm{~b}$ ), among which the field under GA3 $(40 \mathrm{mg} / \mathrm{L})$ increased to a significant level $(p<0.05)$, while the other treatments did not show any significant difference $(p>0.05)$.

Table 4. Effects of uniconazole and GA3 on the Cd Concentration Index (CI) and Translocation Factor (TF) of maize.

\begin{tabular}{|c|c|c|c|}
\hline \multirow{2}{*}{ Treatments } & \multicolumn{2}{|c|}{ Concentration index } & \multirow{2}{*}{ Translocation factor } \\
\cline { 2 - 4 } & Roots & - & $0.873 \pm 0.393 \mathrm{a}$ \\
\hline CK & - & $0.973 \pm 0.076 \mathrm{a}$ & $1.100 \pm 0.519 \mathrm{a}$ \\
\hline A1 & $1.198 \pm 0.656 \mathrm{~b}$ & $0.975 \pm 0.085 \mathrm{a}$ & $0.743 \pm 0.365 \mathrm{ab}$ \\
\hline A2 & $0.763 \pm 0.143 \mathrm{~b}$ & $1.028 \pm 0.135 \mathrm{a}$ & $1.026 \pm 0.155 \mathrm{a}$ \\
\hline A3 & $3.225 \pm 0.504 \mathrm{a}$ & $1.433 \pm 0.718 \mathrm{a}$ & $0.337 \pm 0.166 \mathrm{~b}$ \\
\hline A4 & 24.394 & 1.083 & 3.982 \\
\hline $\begin{array}{c}\text { F value at } \\
p<0.05\end{array}$ & & & \\
\hline
\end{tabular}

In the table, different letters indicate a significant $(p<0.05)$ difference between treatments in the same experiment. 

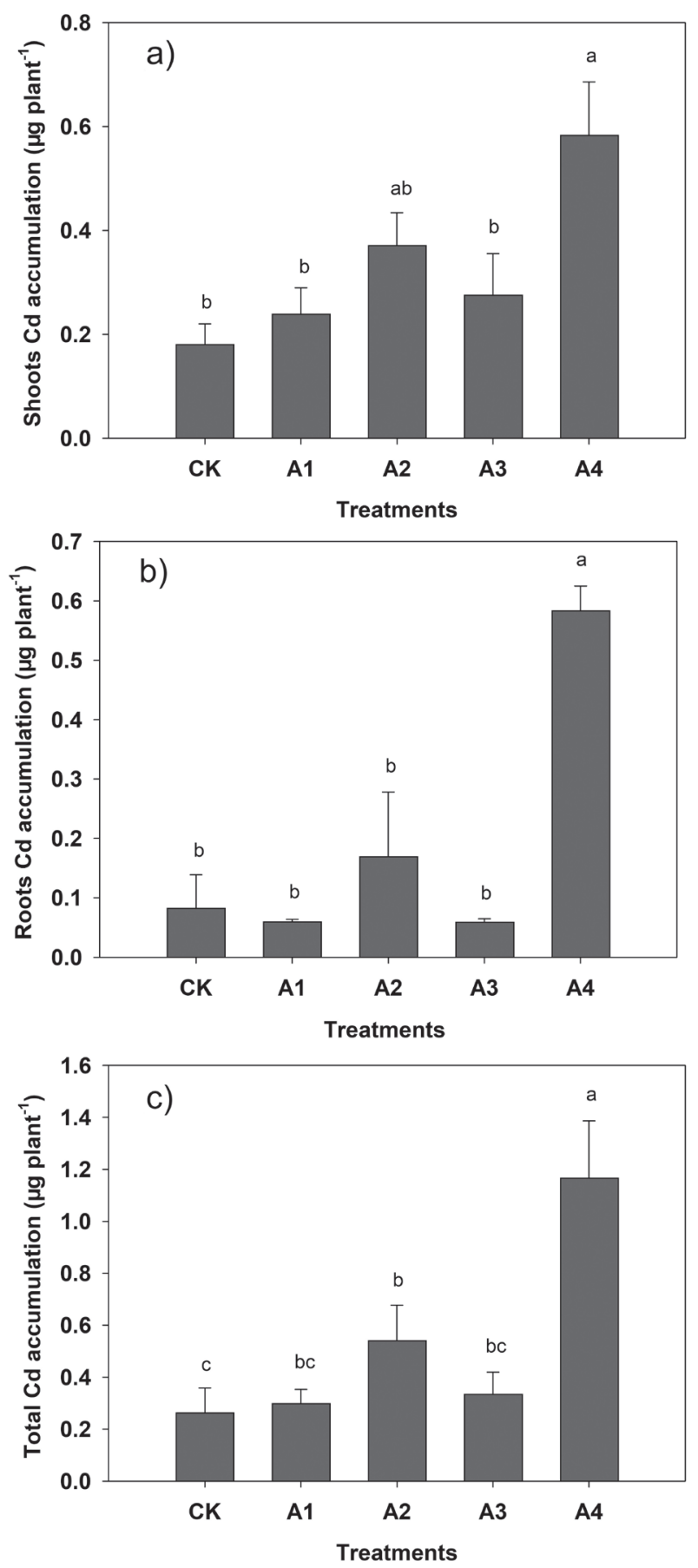

Fig. 7. Effects of uniconazole and GA3 on $\mathrm{Cd}$ accumulation in shoots a), roots b) and total c) of maize.

The accumulation of shoot $\mathrm{Cd}$ in each treatment is shown in Fig. 7a). The $\mathrm{Cd}$ in the plants treated by GA3 $(40 \mathrm{mg} / \mathrm{L})$ increased by $222.01 \%$ compared with that of CK $(p<0.05)$, while uniconazole $(200 \mathrm{mg} / \mathrm{L})$, uniconazole $(800 \mathrm{mg} / \mathrm{L})$ and $\mathrm{GA} 3(10 \mathrm{mg} / \mathrm{L})$ had no significant difference with $\mathrm{CK}(p>0.05)$. In the roots (Fig. 7b), Cd accumulation was shown as the order of $\mathrm{GA} 3(40 \mathrm{mg} / \mathrm{L})>$ uniconazole $(800 \mathrm{mg} / \mathrm{L})>\mathrm{CK}>$ uniconazole $(200 \mathrm{mg} / \mathrm{L})>\mathrm{GA} 3(10 \mathrm{mg} / \mathrm{L})$. The $\mathrm{Cd}$ in the plants treated by GA3 $(40 \mathrm{mg} / \mathrm{L})$ increased by $603.13 \%$ compared with $\mathrm{CK}(p<0.05)$. The $\mathrm{Cd}$ level in the plants treated by uniconazole $(800 \mathrm{mg} / \mathrm{L})$ increased by $105.06 \%$, but the difference did not reach a significant level $(p>0.05)$. The $\mathrm{Cd}$ level in the plants treated by uniconazole $(200 \mathrm{mg} / \mathrm{L})$ and $\mathrm{GA} 3(10 \mathrm{mg} / \mathrm{L})$ were lower than that of CK. In terms of the total Cd accumulation of the whole maize plant (Fig. 7c), the trend was similar to that of the shoot $\mathrm{Cd}$ accumulation, and increased in each treatment compared with $\mathrm{CK}$. The $\mathrm{Cd}$ level in the plants treated by $\mathrm{GA} 3(40 \mathrm{mg} / \mathrm{L})$, uniconazole $(800 \mathrm{mg} / \mathrm{L})$, GA3 $(10 \mathrm{mg} / \mathrm{L})$ and uniconazole $(200 \mathrm{mg} / \mathrm{L})$ increased by $341.70 \%, 105.07 \%, 27.17 \%$ and $13.51 \%$, respectively, among which GA3 $(40 \mathrm{mg} / \mathrm{L})$ and uniconazole $(800$ $\mathrm{mg} / \mathrm{L})$ were significantly different from $\mathrm{CK}(p<0.05)$. It shows that these two plant regulators could promote the absorption of $\mathrm{Cd}$ in maize at high concentrations, but not at low concentrations. The $\mathrm{Cd}$ concentration index (CI) of uniconazole $(800 \mathrm{mg} / \mathrm{L})$ and GA3 $(40 \mathrm{mg} / \mathrm{L})$ in roots was larger than 1 (Table 4), indicating that the $\mathrm{Cd}$ concentration in roots was increased compared with CK. However, the CI of uniconazole $(200 \mathrm{mg} / \mathrm{L})$ and GA3 $(10 \mathrm{mg} / \mathrm{L})$ was less than 1, indicating that the $\mathrm{Cd}$ concentration of both was lower than CK. The CI of GA3 $(40 \mathrm{mg} / \mathrm{L})$ was the highest, and the difference from other treatments was significant $(p<0.05)$. The GA3 $(10 \mathrm{mg} / \mathrm{L}$ and $40 \mathrm{mg} / \mathrm{L})$ treatments increased the shoot $\mathrm{Cd}$ concentration of maize compared with $\mathrm{CK}$, while a decreasing trend was observed in plants treated by uniconazole $(200 \mathrm{mg} / \mathrm{L})$ and uniconazole $(800 \mathrm{mg} / \mathrm{L})$. However, the difference did not reach a significant level $(p>0.05)$. The translocation factor (TF) of GA3 (40 $\mathrm{mg} / \mathrm{L})$ was significantly lower than that of $\mathrm{CK}(p<0.05)$, indicating that the $\mathrm{Cd}$ concentration in maize roots was higher in this treatment.

\section{Discussion}

\section{Plant Growth and Biomass}

Due to the toxicity of heavy metal elements, their accumulation usually inhibits the growth of plants. Plant growth and biomass are negatively influenced by $\mathrm{Cd}$ [32]. In this study, PGRs (GA3 and uniconazole) were selected to effectively increase maize biomass (both aboveground and underground parts), while the dry weight and fresh weight of shoots and roots of the control were at the minimum. Zheng et al. also reported a similar reduction of fresh biomass under $\mathrm{Cd}$ stress in Glycyrrhiza uralensis plants [33]. Hadi et al. [34] reported that the application of GA3 in Cd-polluted soil significantly increases plant growth and biomass. The phenotype of maize in this study, high concentration of GA3 $(40 \mathrm{mg} / \mathrm{L})$ proved significantly increase the plant height, stem diameter, leaf area, root volume, root tip number and total root length of maize, while low concentration of GA3 $(10 \mathrm{mg} / \mathrm{L})$ and uniconazole $(200 \mathrm{mg} / \mathrm{L})$ could not significantly increase the above parameters, part of which even showed a decreasing 
trend. Ji et al. [14] showed that under the stress of $\mathrm{Cd}$, the application of GA3 with concentrations of 10, 100 and $1000 \mathrm{mg} \mathrm{l}^{-1}$ has no significant effect on the root length of Solanum nigrum L, but significantly increases the biomass accumulation. Our study showed that uniconazole was not conducive to the improvement of crop phenotype and had a limited effect on the increase of crop biomass. The suitable amount of GA3 can increase the biomass of crops under Cd stress.

\section{SPAD Value and Photosynthesis}

$\mathrm{Cd}$ at high concentrations in plants can inhibit the photosynthase activity, chlorophyll synthesis, and photosynthetic efficiency $[35,36]$. High levels of Cd ions can reduce plant leaf SPAD values and suppress crop photosynthesis [37]. This study showed that uniconazole $(200 \mathrm{mg} / \mathrm{L})$ and GA3 (40 $\mathrm{mg} / \mathrm{L})$ could increase the SPAD value and the net photosynthetic rate of maize leaves. Previous studies have shown that application of GA3 to soybeans under $\mathrm{Cd}$ stress can increase the contents of chlorophyll a and chlorophyll b in Glycine Max leaves [38]. Application of GA3 has a significant effect on improving the net photosynthetic efficiency of rice (Oryza sativa L.) leaves under Cd stress [39]. In this study, the application of the appropriate concentration of uniconazole and GA3 also showed similar effects on increasing the SPAD value and net photosynthetic rate of maize leaves.

\section{Antioxidant Response}

In this study, malondialdehyde (MDA) and $\mathrm{H}_{2} \mathrm{O}_{2}$ in the control had a higher level than those in the other treatments. However, the application of uniconazole and GA3 could reduce the content of MDA and $\mathrm{H}_{2} \mathrm{O}_{2}$ in maize leaves, and the best effect was achieved by GA3 (40 mg/L), indicating that it could promote free radical scavenging system in leaves of studied plants. In order to prevent ROS from harming cells, efficiently functioning antioxidant defense systems composed of enzymes and non-enzymatic is needed prerequisite [40]. Cd stress changes antioxidant enzyme activities in plants. Superoxide dismutase (SOD) can decompose $\mathrm{O}_{2}^{-}$ into $\mathrm{O}_{2}$ and $\mathrm{H}_{2} \mathrm{O}_{2}$. Its activity change is an important indicator of $\mathrm{O}_{2}^{-}$yield change. In this study, it was found that the activities of SOD and POD in the control plants were lower than those planted treated with uniconazole and GA3 under Cd stress. GA3 treatment enhanced the activities of SOD, POD and CAT in maize leaves, which may be beneficial to reduce the $\mathrm{H}_{2} \mathrm{O}_{2}$ content. Proline is an organic osmotic substance. Environmental stress (such as heavy metals, drought, soil acidification, etc.) can promote the accumulation of proline in plants, which has the function of scavenging reactive oxygen species (ROS) in cells and stabilizing protein structures [1,41]. Our study showed that the application of uniconazole and GA3 could increase the content of proline between in maize leaves by $24.38 \%-41.35 \%$, indicating that both could promote the synthesis of proline in maize leaves under Cd stress. Vitamin E is a fat-soluble chain breaking antioxidant that controls peroxidation and protects plants from oxidative damage by removing or deactivating free radicals [42]. Our results showed that uniconazole and GA3 could promote the increase of vitamin $\mathrm{E}$ in maize leaves, indicating that both had good antioxidant effects on maize under Cd stress. Gong et al. found that application of exogenous calcium and speramine increases the vitamin $\mathrm{E}$ content in ramie [29]. It shows that it is feasible to regulate Cd tolerance of crops by exogenous application of PGRs.

\section{Cd Uptake in Plants}

The results of this study showed that GA3 $(40 \mathrm{mg} / \mathrm{L})$ had no significant effect on the $\mathrm{Cd}$ concentration in the shoots of the maize, but could significantly increase the $\mathrm{Cd}$ concentration in maize root system. This may be because the root system is in contact with $\mathrm{Cd}$ in the cultivated soil, leading to its more accumulation in the roots [43]. In addition, the $\mathrm{Cd}$ accumulation in the shoots and roots of maize treated with GA3 $(40 \mathrm{mg} / \mathrm{L})$ was significantly higher than that of other treatments. This result was supported by Ahmad et al. [44] who found that application of GA3 significantly increases the concentration and accumulation of $\mathrm{Cd}$ in leaves, stems and roots of Veronica anagallis aquatica and Epilobium laxum. Ji also found that applying GA3 with a concentration of $1000 \mathrm{mg} / \mathrm{L}$ could significantly increase the biomass of $S$. nigrum by $56 \%$ [14]. Translocation factor (TF) is an important indicator for plants to transfer heavy metals from contaminated soil to aerial parts. Generally speaking, a higher TF value indicates a higher phytoremediation efficiency [45]. The results of this experiment showed that TF of the plants treated with uniconazole $(200 \mathrm{mg} / \mathrm{L})$ and GA3 $(10 \mathrm{mg} / \mathrm{L})$ was greater than 1 . However, in terms of the total $\mathrm{Cd}$ absorption, GA3 (40 mg/L) had the best effect by increasing the $\mathrm{Cd}$ concentration in the upper and underground parts of maize under Cd stress. The fresh weight of the plant biomass increased, similar to the report by Ji et al. [14]. Cd enriched plants have high $\mathrm{Cd}$ concentrations in the body, but often have low biomass, slow growth and low repair efficiency [46]. Considering the short restoration time of soil $\mathrm{Cd}$ in facilities, the restoration plants should have the characteristics of heat resistance, high humidity resistance and so on. Plant growth regulators can be used to improve the tolerance of $\mathrm{Cd}$ in maize, thereby increasing the biomass and $\mathrm{Cd}$ concentration of maize, which is one of the phytoremediation approaches of Cd-contaminated soil in facilities.

\section{Conclusions}

Maize has the characteristics of fast growth, biomass increase and high temperature resistance, 
which is suitable for planting in the leisure season of the facility vegetable field in summer. In this study, it was found that the adverse effects of Cd stress on maize growth could be alleviated by applying PGRs (GA3 and uniconazole). GA3(40 mg/L) showed the best performance. It could significantly improve the maize growth, enhance the ability to resist oxidative damage, and significantly increase the biomass and $\mathrm{Cd}$ concentration in the shoots and roots of maize. Finally, the absolute amount of $\mathrm{Cd}$ in maize increased significantly. The above results indicate that maize is a potential remediation plant suitable for $\mathrm{Cd}$ contaminated vegetable fields of facilities. Meanwhile, we suggest that in the actual production, before the removal of maize, appropriate wetting soil and deep turning should be adopted to ensure the integrity of the whole plant (roots and shoots) of maize as much as possible, so as to achieve the optimization of the absorption efficiency. This study provides a preliminary basis for improving the phytoremediation efficiency of Cd-contaminated vegetable fields in facilities.

\section{Acknowledgments}

This work was supported by Agriculture Industrial Technology System Funding of Shandong Province of China [Grant numbers: SDAIT-05-07]; Agricultural Scientific and Technological Innovation Project of Shandong Academy of Agricultural Sciences [Grant numbers: CXGC2016B06, CXGC2016A06]; Major Agricultural Application Innovation Project of Shandong Province [6682218040]; National Key R\&D Program of China [Grant numbers: 2016YFD0200402-2]; China Agriculture Research System [Grant numbers: CARS23-G14], and Jinan Top Ten Agricultural Characteristic Industry Science and Technology Innovation Team.

\section{Conflict of Interest}

The authors declare that there is no conflict of interest regarding the publication of this paper.

\section{References}

1. ALI N., HADI F. Phytoremediation of cadmium improved with the high production of endogenous phenolics and free proline contents in Parthenium hysterophorus plant treated exogenously with plant growth regulator and chelating agent. Environmental Science and Pollution Research, 22 (17), 13305, 2015.

2. FAGERBERG B., BARREGARD L., SALLSTEN G., FORSGARD N., ÖSTLING G., PERSSON M., BORNé Y., ENGSTRöM G., HEDBLAD B. Cadmium exposure and atherosclerotic carotid plaques - results from the Malmö diet and Cancer study. Environmental Research, 136, 67, 2015.

3. OKEDEYI O.O., DUBE S., AWOFOLU O.R., NINDI M.N. Assessing the enrichment of heavy metals in surface soil and plant (Digitaria eriantha) around coal-fired power plants in South Africa. Environmental Science and Pollution Research, 21 (6), 4686, 2014.

4. ANSARI M.M., NEHA., KHAN H.A. Effect of cadmium chloride exposure during the induction of collagen induced arthritis. Chemico-Biological Interactions, 238, 55, 2015.

5. ZHANG H.D., HUANG B., DONG L.L., HU W.Y., AKHTAR M.S., QU M.K. Accumulation, sources and health risks of trace metals in elevated geochemical background soils used for greenhouse vegetable production in southwestern China. Ecotoxicology and Environmental Safety, 137, 233, 2017.

6. SUN Y.B., LI Y., XU Y.M., LIANG X.F., WANG L. In situ stabilization remediation of cadmium $(\mathrm{Cd})$ and lead $(\mathrm{Pb})$ co-contaminated paddy soil using bentonite. Applied Clay Science, 105, 200, 2015.

7. DONG J., ZHAO Z.W., LIANG B., LI J.L. The development status of China's facilities and vegetable industry. Chinese Horticulture Abstracts, 33 (01), 75, 2017.

8. SUN K.N., WEN D., YANG N., WANG K.A., LI X.H., YU L. Heavy metal and soil nutrient accumulation and ecological risk assessment of vegetable fields in representative facilities in Shandong Province, China. Environmental Monitoring and Assessment, 191 (4), 2019.

9. ZHANG J., ZHANG G., CAI D., WU Z. Immediate remediation of heavy metal (Cr (VI)) contaminated soil by high energy electron beam irradiation. Journal of Hazardous Materials, 285, 208, 2015.

10. VITHANAGE M., DABROWSKA B.B., MUKHERJEE A.B., SANDHI A., BHATTACHARYA P. Arsenic uptake by plants and possible phytoremediation applications: a brief overview. Environmental Chemistry Letters, 10 (3), 217, 2012

11. MEMON A.R., SCHRöDER P. Implications of metal accumulation mechanisms to phytoremediation. Environmental Science and Pollution Research, 16 (2), 162,2009

12. PERSANS M.W., SALT D.E. Possible molecular mechanisms involved in nickel, zinc and selenium hyperaccumulation in plants. Biotechnology Genetic Engineering Reviews, 17 (1), 389, 2000.

13. HADI F., BANO A. Utilization of Parthenium hysterophorus for theremediation of lead-contaminated soil. Weed Biology and Management, 9 (4), 307, 2009.

14. JI P., TANG X., JIANG Y., TONG Y., GAO P., HAN W. Potential of Gibberellic Acid 3 (GA3) for Enhancing the Phytoremediation Efficiency of Solanum nigrum L. Bulletin Environmental Contamination and Toxicology, 95 (6), 810, 2015.

15. MAHOUACHI J., IGLESIAS D.J., AGYSTI M., TALON M. Delay of early fruitlet abscission by branch girdling in citrus coincides with previous increases in carbohydrate and gibberellin concentrations. Plant Growth Regulation, 58 (1), 15, 2009.

16. NISHIJIMA T., KOSHIOKA M., YAMAZAKI H., MIURA H., MANDER L.N. Endogenous gibberellins and bolting in cultivars of Japanese radish. Acta Horticulturae, 394, 199, 1995.

17. UPADHYAYA A., DAVIS T.D., LARSEN M.H., WALSER R.H., SANKHLA N. Uniconazole-induced thermotolerance in soybean seedling root tissue. Physiologia Plantarum, 79 (1), 78, 1990.

18. HUSSEIN M.M., BAKHETA M.A., ZAKI S.N. Influence of uniconazole on growth characters, photosynthetic pigments, total carbohydrates and total soluble sugars of hordium vulgare 1 plants grown under salinity stress. 
International Journal of Science and Research, 3 (12), 2208, 2014.

19. KIM H.Y., CHOI B.J., SANG C.K. Effects of uniconazole on the drought resistance of Pilea cadierei-(I)Morphological changes and water loss in leaves. Journal of the Korean Society for Horticultural Science, 35, 493, 1994.

20. AHMAD I., KAMRAN M., ALI S., CAI T., BILEGJARGAL B., LIU T.N., HAN Q.F. Seed filling in maize and hormones crosstalk regulated by exogenous application of uniconazole in semiarid regions. Environmental Science and Pollution Research, 25 (33), 33225, 2018.

21. LI L., VANSTADEN J. Effects of plant growth regulators on the antioxidant system in callus of two maize cultivars subjected to water stress. Plant Growth Regulation, 24 (1), 55, 1998.

22. YAN Y.H., YAN W., LIU W.G., WANG X.C., YONG T.W., YANG W.Y., ZHAO L.L. Influence of seed treatment with uniconazole powder on soybean growth, photosynthesis, dry matter accumulation after flowering and yield in relay strip intercropping system. Plant Production Science, 18 (3), 295, 2015.

23. CHAOUI A., MAZHOUDI S., GHORBAL M.H., FERJANI E.E. Cadmium and zinc induction of lipid peroxidation and effects on antioxidant enzymes activities in bean (Phaseolus vulgaris L.). Plant Science, 127 (2), 139, 1997.

24. VELIKOVA V., YORDANOV I., EDREVA A. Oxidative stress and some antioxidant systems in acid rain-treated bean plants: protective role of exogenous polyamines. Plant Science, 151 (1), 59, 2000.

25. STEWART R.R., BEWLEY J.D. Lipid peroxidation associated with accelerated aging of soybean axes. Plant Physiology, 65 (2), 245, 1980.

26. PATRA H.K., KAR M., MISHRA D. Catalase activity in leaves ad cotyledons during plant development and senescence. Biochemical Pharmacology, 172 (4), 385, 1978.

27. NICKEL K.S, CUNNINGHAM B.A. Improved peroxidase assay method using Ieuco 2, 3', 6-trichlcroindophenol and application to comparative measurements of peroxidase catalysis. Analytical Biochemistry, 27 (2), 292, 1969.

28. BATES L.S., WALDREN R.P., TEARE I.D. Rapid determination of free proline for water stress studies. Plant and Soil, 39 (1), 205, 1973.

29. GONG X.M., LIU Y.G., HUANG D.L., ZENG G.M., LIU S.B., TANG H., ZHOU L., HU X., ZHOU Y.Y., TAN X.F. Effects of exogenous calcium and spermidine on cadmium stress moderation and metal accumulation in Boehmeria nivea (L.) Gaudich. Environmental Science and Pollution Research, 23 (9), 8699, 2016.

30. BAUDDH K., SINGH R.P. Growth, tolerance efficiency and phytoremediation potential of Ricinus communis (L.) and Brassica juncea (L.) in salinity and drought affected cadmium contaminated soil. Ecotoxicology and Environmental Safety, 85, 13, 2012.

31. KIEKENS L., CAMERLYNCK R. Transfer characteristics for uptake of heavy metals by plants. Landwirtsch Forsch, 39, 255, 1982.

32. HADI F., BANO A., FULLER M.P. The improved phytoextraction of lead $(\mathrm{Pb})$ and the growth of maize (Zea mays L.): the role of plant growth regulators (GA3 and IAA) and EDTA alone and in combinations. Chemosphere, 80 (4), 457, 2010.

33. ZHENG G., LV H.P., GAO S., WANG S.R. Effects of cadmium on growth and antioxidant responses in Glycyrrhiza uralensis seedlings. Plant Soil and Environment. 56 (11), 508, 2010.

34. HADI F., ALI N., AHMAD A. Enhanced phytoremediation of cadmium-contaminated soil by Parthenium hysterophorus plant: Effect of gibberellic acid (GA3) and synthetic chelator, alone and in combinations. Bioremediation Journal, 18 (1), 46, 2014.

35. THAPAR R., SRIVASTAVA A.K., BHARGAVA P., MISHRA Y., RAI L.C. Impact of different abiotic stress on growth, photosynthetic electron transport chain, nutrient uptake and enzyme activities of $\mathrm{Cu}$-acclimated Anabaena doliolum. Journal of Plant Physiology, 165 (3), 306, 2008.

36. VAJPAYEE P., TRIPATHI R.D., RAI U.N., ALI M.B., SINGH S.N. Chromium (VI) accumulation reduces chlorophyll biosynthesis, nitrate reductase activity and protein content in Nymphaea alba L. Chemosphere, 41 (7), 1075, 2000

37. DONG J., WU F.B., ZHANG G.P. Effect of cadmium on growth and photosynthesis of tomato seedlings. Journal of Zhejiang University Sciences, 6B (10), 974, 2005.

38. GHORBANLI M., SEPEHR M.F., KAVEH S.H. Effects of cadmium and gibberellin on growth and photosynthesis of Glycine max. Photosythetica, 37 (4), 627, 2000.

39. MOYA J.L., ROS R., PICAZO I. Heavy metal-hormone interactions in rice plants: Effects on growth, net photosynthesis, and carbohydrate distribution. Journal of Plant Growth Regulation, 14 (2), 61, 1995.

40. ZHENG M., TAO Y., HUSSAIN S., JIANG Q., PENG S., HUANG J., CUI K., NIE L. Seed priming in dry directseeded rice: consequences for emergence, seedling growth and associated metabolic events under drought stress. Plant Growth Regulation, 78 (2), 167, 2015.

41. VERBRUGGEN N., HERMANS C. Proline accumulation in plants: a review. Amino Acids, 35, 753, 2008.

42. CARETTO S., PARADISO A., D'AMICO L., DE GARA. L. Ascorbate and glutathione metabolism in two sunflower cell lines of differing $\alpha$ - tocopherol biosynthetic capability. Plant Physiology and Biochemistry, 40 (6-8), 509, 2002.

43. ANJUM S.A., TANVEER M., HUSSAIN S., BAO M., WANG L.C., KHAN I., ULLAH E., TUNG S.A., SAMAD R.A., SHAHZAD B. Cadmium toxicity in maize (Zea mays L.): consequences on antioxidative systems, reactive oxygen species and cadmium accumulation. Environmental Science and Pollution Research, 22 (21), 17022, 2015.

44. AHMAD A., HADI F., ALI N., JAN A.U. Enhanced phytoremediation of cadmium polluted water through two aquatic plants Veronica anagallis-aquatica and Epilobium laxum. Environmental Science and Pollution Research, 23 (17), 17715, 2016.

45. DOTY S.L. Enhancing phytoremediation through the use of transgenics and endophytes. New Phytologist, 179 (2), 318, 2008.

46. WANG W.Z., XU W.H., ZHOU K., XIONG Z.T. Research progressing of present contamination of $\mathrm{Cd}$ in soil and restoration method. Wuhan University Journal of Natural Science, 20 (5), 430, 2015. 
